\title{
Assessment of the Correlation and Path Analysis with Association of Growth and Yield Characteristics in Okra
}

\author{
Inderpreet Kaur Binepal*, Swati Barche, Mandeep Kaur and K.P. Asati
}

Department of Vegetable Science, Rajmata Vijayaraje Scindia Krishi Vishwavidyalaya, Indore - 452001 (MP) India

*Corresponding author

\begin{tabular}{|l|}
\hline Ke y w o r d s \\
$\begin{array}{l}\text { Correlation } \\
\text { analysis, Path } \\
\text { analysis, Growth } \\
\text { and yields of okra }\end{array}$ \\
\hline Article Info \\
\hline $\begin{array}{l}\text { Accepted: } \\
18 \text { April } 2019 \\
\text { Available Online: } \\
10 \text { May } 2019\end{array}$ \\
\hline
\end{tabular}

A B S T R A C T

The present investigations were conducted at Nursery area, Department of Horticulture, College of Agriculture, Indore, M.P. during kharif season of 2016. The experiment was laid out in Randomized Completely Block Design (RCBD) with three replications and eighteen genotypes were collected i.e. Shakti, Jhilmil, No. 55, Sahiba, No. 64, Harita, Saarika, Ns-801, Arya Mohini, Shaan, Hissar Unnat, Panchwati, Panchali, Swati, Lakshmi, $\mathrm{OH}-102$, Shankar Ganga and Parbhani Kranti. The genotype Panchwati was recorded maximum in growth and yield characters like number of branches plant ${ }^{-1}$, number of leaves plant ${ }^{-1}$, fruit length $(16.23 \mathrm{~cm})$, fruit width $(2.14 \mathrm{~cm})$, fruit weight $(17.15 \mathrm{gm})$, number of fruit plant ${ }^{-1}(14.53)$, fruit yield plant ${ }^{-1}(292.17 \mathrm{gm})$, fruit yield plot $^{-1}(11.62 \mathrm{~kg})$, and fruit yield ha ${ }^{-1}(161.28 \mathrm{q})$. The highest positive and significant correlation coefficient of fruit yield plant ${ }^{-1}$ was observed with number of fruits plant ${ }^{-1}$ and fruit length. The highest positive and significant correlation coefficient of fruit yield plant ${ }^{-1}$ has been noted with number of fruits plant ${ }^{-1}$ indicating that these characters is the primary yield determinant in okra. The yield attributing characters exhibited varying trend amongst them. Path coefficient analysis revealed that number of fruits plant ${ }^{-1}$ had highest positive direct effect followed by fruit weight, number of nodes to first flowering, number of branches plant ${ }^{-1}$ at 90 DAS (days after sowing), length of internodes, number of leaves plant ${ }^{-1}$ at 90 DAS, plant height at 90 DAS and fruiting span are the most important character contributing towards fruit yield and hence purposeful and balance selection based on these character would be rewarding improvement in okra. Direct selection of fruit yield plant ${ }^{-1}$, days to $50 \%$ flowering, days to first flowering, fruit length and days to first picking should be avoided instead of direct selection.

\section{Introduction}

Okra [Abelmoschus esculentus (L.) Moench] belongs to the family Malvaceae having chromosome no. $2 \mathrm{n}=130$ has captured a prominent position among vegetables. These studies along with the association analysis will be more useful in the estimation of interrelationship among the growth and yield contributing components. It is essential to have detail information on the association among different yield components and their 
relative contribution to yield. Association analysis of quantitative attributes would help in choosing component characters that are positively correlated.

In addition, an understanding of association between the component characters is essential to judge their rational importance. Path coefficient analysis is also very useful in formulating breeding strategy to develop elite genotypes through selection in advanced generations. Thus, the nature and magnitude of variability present in the gene pool for different characters and relationship with each other determine the success of genetic improvement of characters. Since the pattern of inheritance of quantitative characters is highly complex. Therefore the present investigation was undertaken to study the association among different components of growth and yield and their direct and indirect contribution to fruit yield in okra.

\section{Materials and Methods}

An experiment was conducted at Nursery area, Department of Horticulture, College of Agriculture, Indore, MP during Kharif season of 2016. The experiment was laid out in a Randomized Completely Block Design with three replications. The experimental material consisted of eighteen genotypes of okra. Seed of germplasm were collected from different location of India. The seeds were sown in July in field in fifty four separate plots. The plot size was kept $4.2 \mathrm{~m}$ x $2.5 \mathrm{~m}$. Each plot consisted of thirty five plants. Correlation coefficients were calculated in all possible combinations taking all the characters into consideration at genotypic, phenotypic and environmental levels by using the formula as proposed by Miller et al., (1958).The direct and indirect contribution of various independent characters on a dependent character yield were calculated through path coefficient analysis as suggested by Wright
(1921) and elaborated by Dewey and Lu (1959). The following set of simultaneous equation were formed and used for the estimation of direct and indirect effects. The analysis of variance was carried out as per methods suggested by Panse and Sukhatme (1967).

\section{Results and Discussion}

\section{Correlation coefficient analysis}

A wide range of variation in quantitative characters provides the basis for selection in plant breeding programme. The knowledge of association among the characters is useful to the breeder for improving the efficiency of selection. Correlation coefficient analysis measures the mutual relationship between growth and yield characters of plant and determines the component character on which selection can be made for genetic improvement of yield. Investigation regarding the presence of component and nature of association among themselves is essential and pre-requisite for improvement in yield. Correlation coefficient provides a clear picture of the extent of association between a pair of traits and indicates whether simultaneous improvement of the correlated traits may be possible or not.

The knowledge of genetic association between yield and its component characters help in improving the efficiency of selection for yield by making proper choice and balancing one component with another. The magnitude of genotypic correlation has been found higher than the phenotypic correlation for all the traits that indicated inherent association between various characters. The similar findings are in agreement with the finding of Niranjan and Mishra (2003), Kumar et al., (2009), Senapati et al., (2011), Saryam et al., (2015) and Khajuria et al., (2016) (Table 1 and 2). 
Correlation between yield and its components

In the present findings significant positive phenotypic correlation of fruit yield plant ${ }^{-1}$ has been observed with fruit weight, number of fruits plant ${ }^{-1}$, number of branches plant ${ }^{-1}$ at 90 DAS, number of leaves plant ${ }^{-1}$ at 90 DAS, fruit width, days to first picking and days to $50 \%$ flowering. The highest positive and significant correlation coefficient of fruit yield plant ${ }^{-1}$ has been recorded with fruit weight, number of fruits plant $^{-1}$, number of branches plant ${ }^{-1}$ at 90 DAS, number of leaves plant $^{-1}$ at 90 DAS, fruit width, days to first picking and days to $50 \%$ flowering indicating that these characters are the primary yield determination in okra. These findings corroborated with the earlier findings of Gandhi et al., (2002), Jaiprakashnarayan and Mulge (2004), Bhalekar et al., (2005), Nimbalkar et al., (2002), Niranjan and Mishra (2003), Ghosh (2005), Choudhary (2006) and Verma et al., (2007) for fruit weight, number of fruit plant ${ }^{-1}$, number of branches plant ${ }^{-1}$ and fruit width. Yonas et al., (2014) and Saryam et al., (2015) for fruit weight, number of fruits plant $^{-1}$ and fruit width. Khajuria et al., (2016) for number of fruits plant ${ }^{-1}$.

\section{Correlation between yield contributing characters}

Plant height at 90 DAS was recorded highly significant and positive association with length of internodes. Whereas, highly significant and negative association with number of branches plant ${ }^{-1}$ at 90 DAS. These results are in corroborated with the findings of Ali et al., (2008) and Saryam et al., (2015) for length of internodes. Association of number of branches plant ${ }^{-1}$ at 90 DAS was recorded significant and positive with number of fruit plant $^{-1}$, fruit yield plant ${ }^{-1}$, number of leaves plant $^{-1}$ at $90 \mathrm{DAS}$, fruit weight, fruit width and fruit length. These results are in close harmony with the findings of Saryam et al., (2015) for fruit length, fruit width, fruit weight and number of fruits plant ${ }^{-1}$ and Sharma and Prasad (2015) for number of fruits plant ${ }^{-1}$. Association of number of leaves plant $^{-1}$ at 90 DAS was recorded significant and positive with fruit length, fruit width, fruit yield plant ${ }^{-1}$, fruit weight and number of fruit plant $^{-1}$. The positive correlation of number of leaves plant ${ }^{-1}$ at 90 DAS with fruit length, fruit width, fruit yield plant ${ }^{-1}$, fruit weight and number of fruit plant ${ }^{-1}$ indicates that allocation and translocation of photosynthates from the source to the sink. These results are in close harmony with the findings of Nagre et al., (2011) for fruit length and weight.

Association of days to first flowering was exhibited significant and positive with days taken to 50\% flowering, days to first picking and number of fruits plant ${ }^{-1}$. These result closely similar with the finding of Sharma and Prasad (2015) for days to 50\% flowering and days to first picking. Days to $50 \%$ flowering was recorded highly significant and positive association with days to first picking, fruit length, number of fruit plant ${ }^{-1}$ and fruit yield plant $^{-1}$. These findings corroborated the earlier finding of Sharma and Prasad (2010) for days to first picking and Mishra et al., (2015) for days to first picking. Association of days to first picking was exhibited highly significant and positive with fruit length, fruit weight, number of fruit plant ${ }^{-1}$ and fruit yield plant $^{-1}$. These findings corroborated the earlier finding of Sharma and Prasad (2015) for number of fruit plant ${ }^{-1}$. Fruit length expressed highly significant and positive correlation with fruit width, fruit weight, number of fruit plant ${ }^{-1}$ and fruit yield plant ${ }^{-1}$. These findings corroborated the previously finding of Ghosh (2005) for fruit yield plant ${ }^{-1}$, Osekita and Akinyele (2008) for fruit weight and Saryam et al., (2015) for number of fruits plant $^{-1}$ and Pachiyappan and Saravannan (2016) for fruit length. 
Table.1 Genotypic path coefficients showing direct and indirect effects of different characters on fruit yield per plant (g) in okra

\begin{tabular}{|c|c|c|c|c|c|c|c|c|c|c|c|c|c|}
\hline Characters & 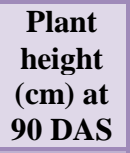 & $\begin{array}{c}\begin{array}{c}\text { No. of } \\
\text { branches }\end{array} \\
\text { plant }^{-1} \text { at } 90 \\
\text { DAS } \\
\end{array}$ & 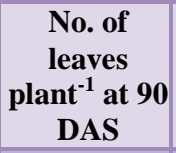 & $\begin{array}{c}\text { No. of } \\
\text { nodes at } \\
1^{\text {st flowering }}\end{array}$ & $\begin{array}{l}\begin{array}{c}\text { Length of } \\
\text { internodes } \\
\text { (cm) }\end{array} \\
\end{array}$ & $\begin{array}{l}\text { Days to } 1^{\text {st }} \\
\text { flowering }\end{array}$ & $\begin{array}{l}\text { Days to } 50 \% \\
\text { flowering }\end{array}$ & $\begin{array}{l}\text { Days to } \\
\text { first } \\
\text { picking }\end{array}$ & $\begin{array}{c}\text { Fruit } \\
\text { length } \\
(\mathrm{cm})\end{array}$ & \begin{tabular}{|c|} 
Fruit \\
width $(\mathrm{cm})$
\end{tabular} & $\begin{array}{c}\begin{array}{c}\text { Fruit } \\
\text { weight }(g)\end{array} \\
\end{array}$ & $\begin{array}{l}\text { No. of fruit } \\
\text { plant }^{-1}\end{array}$ & $\begin{array}{l}\text { "r" value } \\
\text { Fruit yield } \\
\text { plant }^{-1}(g)\end{array}$ \\
\hline $\begin{array}{l}\text { Plant height } \\
\text { (cm) at } 90 \text { DAS }\end{array}$ & 0.2485 & -0.5142 & -0.0940 & -0.0107 & -0.0073 & 0.2541 & -0.1270 & 0.0843 & -0.0085 & 0.1272 & 0.0107 & 0.0210 & -0.016 \\
\hline $\begin{array}{l}\text { No. of branches } \\
\text { plant }^{-1} \text { at } 90 \\
\text { DAS }\end{array}$ & 0.0933 & 1.3702 & -0.3310 & -0.0059 & 0.0009 & -0.2212 & 0.2041 & 0.0179 & 0.1026 & -0.3050 & 0.1463 & -0.1657 & 0.720 \\
\hline $\begin{array}{l}\text { No. of leaves } \\
\text { plant }^{-1} \text { at } 90 \\
\text { DAS }\end{array}$ & 0.0437 & 0.8489 & -0.5342 & 0.0062 & -0.0038 & 0.0222 & 0.1568 & 0.0800 & 0.1620 & -0.3132 & 0.1166 & -0.0843 & 0.501 \\
\hline $\begin{array}{l}\text { No. of nodes at } \\
\text { first flowering }\end{array}$ & 0.0622 & 0.1905 & 0.0769 & -0.0427 & 0.0006 & -0.0697 & -0.1856 & 0.1793 & -0.0223 & 0.0337 & 0.0281 & -0.0568 & 0.194 \\
\hline $\begin{array}{l}\text { Length of } \\
\text { internodes }(\mathrm{cm})\end{array}$ & 0.1256 & -0.0855 & -0.1410 & 0.0018 & -0.0144 & 0.0385 & 0.0167 & -0.1594 & -0.0177 & 0.1392 & -0.0453 & 0.0061 & -0.135 \\
\hline $\begin{array}{l}\text { Days to } 1^{\text {st }} \\
\text { flowering }\end{array}$ & $0.0610^{-}$ & 0.2926 & 0.0115 & -0.0029 & 0.0005 & -1.0357 & 0.7214 & 0.3261 & 0.0104 & 0.0946 & 0.0431 & -0.0939 & 0.307 \\
\hline $\begin{array}{l}\text { Days to } 50 \% \\
\text { flowering }\end{array}$ & 0.0372 & 0.3300 & -0.0988 & 0.0094 & -0.0003 & -0.8814 & 0.8477 & 0.3189 & 0.1026 & -0.1573 & 0.0864 & -0.0921 & 0.428 \\
\hline $\begin{array}{l}\text { Days to1st } \\
\text { picking }\end{array}$ & 0.0338 & 0.0395 & -0.0689 & -0.0124 & 0.0037 & -0.5446 & 0.4358 & 0.6201 & 0.1070 & -0.0830 & 0.1140 & -0.1039 & 0.541 \\
\hline Fruit length $(\mathrm{cm})$ & $\begin{array}{r}- \\
0.0098\end{array}$ & 0.6496 & -0.3999 & 0.0044 & 0.0012 & -0.0496 & 0.4020 & 0.3065 & 0.2164 & -0.4878 & 0.1571 & -0.1138 & 0.676 \\
\hline Fruit width (cm) & 0.0537 & 0.7105 & -0.2845 & 0.0024 & 0.0034 & 0.1666 & 0.2267 & 0.0875 & 0.1795 & -0.5882 & 0.1053 & -0.0834 & 0.472 \\
\hline Fruit weight (g) & 0.0126 & 0.9521 & -0.2957 & -0.0057 & 0.0031 & -0.2119 & 0.3479 & 0.3357 & 0.1615 & -0.2940 & 0.2106 & -0.1917 & 1.025 \\
\hline $\begin{array}{l}\text { No. of } \\
\text { fruitsplant }^{-1}\end{array}$ & $0.0263^{-}$ & 1.1455 & -0.2272 & -0.0122 & 0.0004 & -0.4906 & 0.3938 & 0.3251 & 0.1243 & -0.2475 & 0.2036 & -0.1982 & 0.991 \\
\hline
\end{tabular}

Residual effect Genotypic: 0.0229 
Table.2 Phenotypic path coefficients showing direct and indirect effects of different characters on pod yield plant ${ }^{-1}(\mathrm{~g})$ in okra

\begin{tabular}{|c|c|c|c|c|c|c|c|c|c|c|c|c|c|}
\hline Characters & $\begin{array}{c}\text { Plant } \\
\text { height } \\
(\mathrm{cm}) \text { at } 90 \\
\text { DAS }\end{array}$ & $\begin{array}{c}\text { No. of } \\
\text { branches } \\
\text { plant }^{-1} \text { at } \\
90 \text { DAS }\end{array}$ & $\begin{array}{c}\begin{array}{c}\text { No. of } \\
\text { leaves } \\
\text { plant }^{-1} \text { at } \\
\text { 90 DAS }\end{array} \\
\end{array}$ & $\begin{array}{c}\text { No. of } \\
\text { nodes at } \\
1^{\text {st floweri }} \\
\text { ng } \\
\end{array}$ & $\begin{array}{l}\text { Length of } \\
\text { internodes } \\
\text { (cm) }\end{array}$ & $\begin{array}{l}\text { Days to } 1^{\text {st }} \\
\text { flowering }\end{array}$ & $\begin{array}{c}\text { Days to } \\
50 \% \\
\text { flowering }\end{array}$ & $\begin{array}{c}\text { Days to } \\
\text { first } \\
\text { picking }\end{array}$ & $\begin{array}{c}\text { Fruit } \\
\text { length } \\
(\mathrm{cm})\end{array}$ & $\begin{array}{l}\text { Fruit } \\
\text { width } \\
\text { (cm) }\end{array}$ & $\begin{array}{c}\text { Fruit weight } \\
\text { (g) }\end{array}$ & $\begin{array}{l}\text { No. of } \\
\text { fruit } \\
\text { plant }^{-1}\end{array}$ & $\begin{array}{l}\text { "r" value } \\
\text { Fruit yield } \\
\text { plant }^{-1} \text { (g) }\end{array}$ \\
\hline Plant height $(\mathrm{cm})$ at 90 DAS & 0.1024 & -0.0405 & -0.0076 & -0.0048 & -0.0268 & -0.0064 & -0.0008 & -0.0037 & -0.0006 & -0.0080 & 0.0093 & -0.0391 & -0.027 \\
\hline $\begin{array}{l}\text { No. of branches plant }{ }^{-1} \text { at } 90 \\
\text { DAS }\end{array}$ & -0.0295 & 0.1405 & -0.0306 & -0.0007 & 0.0073 & 0.0036 & 0.0013 & -0.0001 & 0.0202 & 0.0179 & 0.2431 & 0.2672 & 0.640 \\
\hline $\begin{array}{l}\text { No. of leaves plant }{ }^{-1} \text { at } 90 \\
\text { DAS }\end{array}$ & 0.0122 & 0.0674 & -0.0638 & 0.0030 & -0.0125 & -0.0003 & 0.0014 & -0.0028 & 0.0313 & 0.0205 & 0.2351 & 0.1762 & 0.468 \\
\hline No. of nodes at first flowering & 0.0224 & 0.0044 & 0.0088 & -0.0218 & -0.0020 & 0.0055 & -0.0009 & -0.0056 & -0.0072 & 0.0004 & 0.0776 & 0.0665 & 0.148 \\
\hline Length of internodes (cm) & 0.0464 & -0.0173 & -0.0135 & -0.0008 & -0.0591 & -0.0014 & -0.0003 & 0.0071 & -0.0036 & -0.0084 & -0.0479 & -0.0160 & -0.115 \\
\hline Days to $1^{\text {st }}$ flowering & -0.0178 & 0.0136 & 0.0005 & -0.0033 & 0.0022 & 0.0370 & 0.0050 & -0.0112 & -0.0004 & -0.0062 & 0.0891 & 0.1164 & 0.225 \\
\hline Days to $50 \%$ flowering & -0.0112 & 0.0238 & -0.0115 & 0.0025 & 0.0022 & 0.0248 & 0.0075 & -0.0155 & 0.0165 & 0.0068 & 0.0873 & 0.1484 & 0.282 \\
\hline Days to1st picking & 0.0110 & 0.0005 & -0.0053 & -0.0036 & 0.0122 & 0.0121 & 0.0034 & -0.0342 & 0.0222 & 0.0032 & 0.2367 & 0.1454 & 0.404 \\
\hline Fruit length $(\mathrm{cm})$ & -0.0011 & 0.0545 & -0.0384 & 0.0030 & 0.0041 & -0.0003 & 0.0024 & -0.0146 & 0.0520 & 0.0271 & 0.3089 & 0.2110 & 0.609 \\
\hline Fruit width $(\mathrm{cm})$ & -0.0199 & 0.0610 & -0.0317 & -0.0002 & 0.0121 & -0.0055 & 0.0012 & -0.0027 & 0.0341 & 0.0413 & 0.2155 & 0.1390 & 0.444 \\
\hline Fruit weight (g) & 0.0018 & 0.0650 & -0.0285 & -0.0032 & 0.0054 & 0.0063 & 0.0013 & -0.0154 & 0.0306 & 0.0169 & 0.5255 & 0.3020 & 0.908 \\
\hline No. of fruitsplant ${ }^{-1}$ & -0.0099 & 0.0926 & -0.0277 & -0.0036 & 0.0023 & 0.0106 & 0.0028 & -0.0123 & 0.0270 & 0.0142 & 0.3915 & 0.4054 & 0.893 \\
\hline
\end{tabular}

Residual effect Phenotypic: 0.0535 
Fruit width expressed highly significant and positive correlation with fruit weight, number of fruit plant ${ }^{-1}$ and fruit yield plant ${ }^{-1}$. These results are in close agreement with the findings of Bendale et al., (2003), Pawar (2005) and Choudhary (2006), Yonas et al., (2014), Sreenivas et al., (2015) and Saryam et al., (2015) for fruit yield plant ${ }^{-1}$ and fruit weight. Fruit weight expressed highly significant and positive correlation with number of fruit plant ${ }^{-1}$ and fruit yield plant $^{-1}$. These findings corroborated the earlier finding of Sharma and Prasad (2015), Saryam et al., (2015), Sreenivas et al., (2015) and Shivaramegowda et al., (2016) for number of fruit plant ${ }^{-1}$ and fruit yield plant $^{-1}$. The correlation coefficient of number of fruits plant $^{-1}$ was noticed to be significant and it was positively correlated with fruit yield plant $^{-1}$. These findings corroborated the earlier finding of Nagre et al., (2011), Saryam et al., (2015), Sharma and Prasad (2015) and Shivaramegowda et al., (2016).

\section{Path coefficient analysis}

Correlation coefficient is the indication of simple association between variables. In a biological system, however the relationship may exist in a very complex form. It is therefore, essential to study the relationship among variables in a comprehensive way. Path coefficient analysis is a powerful tool. Which enable portioning of the given relationship in its further components. In other words, it takes into account not only the relationship of components character with the dependent character, but simultaneously takes care of its relationship with other components also. Thus, it helps in understanding the casual system in a better way because it enables portioning the total correlation coefficient into direct and indirect effects of various growth and yield characters. In order to see the casual factor and so as to identify the components which are responsible for producing fruit yield plant ${ }^{-1}$. In general, the genotypic direct as well as indirect effects were slightly higher in magnitude as compared to corresponding phenotypic direct and indirect effects indicating that the masking effects of the environment. Path coefficient analysis of different characters contributing towards fruit yield plant ${ }^{-1}$ showed that number of branches plant ${ }^{-1}$ at 90 DAS had highest positive direct effect followed by days to $50 \%$ flowering, days to first picking, plant height at 90 DAS, fruit length and fruit weight. The results are in propinquity with Sarkar et al., (2004), Magar et al., (2009), Ramanjinappa et al., (2011), Das et al., (2012) and Gangashetti et al., (2013). Yonas et al., (2014) for fruit weight and Saryam et al., (2015) for number of branches plant ${ }^{-1}$, Kumar et al., (2016) for fruit weight.

The character fruit yield plant ${ }^{-1}$ showed that number of branches plant ${ }^{-1}$ at 90 DAS had highest positive direct effect followed by days to $50 \%$ flowering, days to first picking, plant height at 90 DAS, fruit length and fruit weight had correlation coefficient value at par with direct effect on fruit yield plant ${ }^{-1}$ and direct selection for these traits would result in higher breeding efficiency for improving yield. Thus, these traits might be reckoned as the most important components traits for fruit yield plant $^{-1}$. Whereas, days to first flowering had the highest negative direct effect on fruit yield plant $^{-1}$ followed by fruit width, number of leaves plant ${ }^{-1}$ at $90 \mathrm{DAS}$, number of fruits plant $^{-1}$, number of nodes at first flowering and length of internodes. The result are in propinquity with Sharma and Prasad (2015) and Sreenivas et al., (2015) for days to first picking and Sharyam et al., (2015) for number of fruits per plant. An overall observation of path coefficient analysis of fruit yield plant ${ }^{-1}$ with its components viz., plant height at 90 DAS, number of branches plant $^{-1}$ at 90 DAS, number of leaves plant ${ }^{-1}$ at 90 DAS, days to first flowering, days to $50 \%$ 
flowering, days to first picking, fruit length, fruit weight, fruit width, number of fruits per plant, number of nodes at first flowering and length of internodes, played an important role in determining the fruit yield plant ${ }^{-1}$, Kumar et al., (2016).

\section{References}

Ali, S., Singh, B., Dhaka, A. and Kumar, D. (2008). Study on correlation coefficients in okra [Abelmoschus esculentus (L.) Moench.]. Plant Archives. 8(1): 405-407.

Bendale, V.W., Kadam, S.R., Bhave, S.G., Mehta, J.L. and Pethe, U.B. (2003). Genetic variability and correlation studies in okra. Orissa J. Hort. 31(2): 1-4.

Bhalekar, S.G., Nimbalkar, C.A. and Desair, U.T. (2005). Correlation and path analysis studies in okra. J. Maharashtra Agric. Univ., 30(1): 109-112.

Choudhary, A.K. (2006). Genetic behaviour of yield and its components in hybrid okra [Abelmoschus esculentus (L.) Moench]. M.Sc. (Ag.) Thesis, J.N.K.V.V., Jabalpur.

Das, S., Chattopadhyay, A., Chattopadhyay, S.B., Dutta, S.and Hazara, P. (2012). Genetic parameters and path analysis of yield and its components in okra at different sowing date in Gangetic plains of eastern India. African J. of Biotechnology. 11(95):1613216141.

Dewey, D.R. and Lu, K.H. (1959). Correlation and path coefficient analysis of components of crested wheat grass read production. Agron. J. 57:515-518.

Gandhi, H.T., Yadav, M.D. and Navale, P.A. (2002). Character association and path analysis in okra. J. Maharashtra Agri. Univ. 27(1): 110-112.

Gangashetti, P.I., Malakannavar, L. and Adiger, S. (2013).Breeding investigations in single and double cross $\mathrm{F}_{4}$ and $\mathrm{F}_{5}$ populations of bhendi [Abelmoschus esculentus (L.) Moench.]. Molecular Plant Breeding. 96106.

Ghosh, J.S. (2005). Genetic variability and correlation studies in Okra. [Abelmoschus esculentus (L.) Moench ]. M.Sc (Ag) Thesis, J.N.K.V.V., Jabalpur.
Jaiprakashnarayan, R.P. and Mulge, R. (2004). Correlation and path analysis in okra [Abelmoschus esculentus (L.) Moench]. Indian J. Hort. 61(3): 232-235.

Khajuria, R.K., Sharma, J.P., Samnotra, R.K., Kumar, S. and Kaki, R. (2016). Variability studies in okra [Abelmoschus esculentus (L.) Moench].Green Farming Vol.7(2) : 266-271.

Kumar, A., Kumar, S. and Maji, S. (2016). Genetic Variability, Heritability and Genetic Advance Studies in Okra [Abelmoschus esculentus (L.) Moench ].Int. J.of Agri. Sci. 57(8): 3122-3124.

Kumar, S., Annapurna, and Yadav, Y.C. (2009). Correlation Coefficient and Path Analysis Studies in Okra [Abelmoschus esculentus (L.) Moench]. Annals of Horticulture. 2(2); 105-108.

Magar, R.G. and Madrap, I.A. (2009). Genetic variability, correlation and path coefficient analysis in okra [Abelmochus esculentus (L.) Monch.]. J. of Plant Sci. (Muzaffarnagar). 4(2):498-501.

Miller, D.A., Williams, J.C., Robinson, H.F. and Comstock, K.B. (1958). Estimates of genotypic and environmental variances and covariances in upland cotton and their implication in selection. Agron. J., 50 : 126131

Mishra, A., Mishra, H.N., Senapati, N. and Tripathy, P. (2015). Genetic variability and correlation studies in Okra (Abelmoschus esculentus (L.) Monech). Electronic J. of Plant Breeding, 6(3):866-869.

Nagre, P.K., Sawant, S.N., Wagh, A.P., Paithankar, D.H. and Joshi, P.S. (2011). Genetic variability and correlation studies in okra. Abstracts of National Symposium on Vegetable Biodiversity, held at JNKVV, Jabalpur, during April 4-5, 2011. pp 4.

Nimbalkar, C.A., Navale, P.A. and Gandhi, H.T. (2002). Regression approach for selecting high yielding genotypes in okra. J. of Maharashtra Agric. Universities. 27(1): 4648.

Niranjan, R.S. and Mishra, M.N. (2003). Correlation and path coefficient analysis in okra (Abelmoschus esculentus Moench). Pro. Hort., 35(2):192-195.

Osekita, O.S. and Akinyele, B.O. (2008). Genetic 
analysis of quantitative traits in ten cultivars of okra (Abelmoschus esculentus (Linn.) Moench). Asian Journal of Plant Sciences. 7(5): 510-513.

Pachiyappan, R. and Saravannan, K. (2016). Studies on genetic variability and correlation for fruit yield and fruit quantity characters of okra. Asian J. Hort., 11(1) : 101-104.

Panse, V.G. and Sukhatme, P.V. (1967). Statistical methods for agricultural workers. 2nd edn. ICAR, New Delhi, India, 381p.

Pawar, S.K. (2005). Genetic analysis of yield and its components in okra [Abelmoschus esculentus (L.) Moench] M.Sc. (Ag.) Thesis, J.N.K.V.V., Jabalpur.

Ramanjinappa, V., Patil, M.G., Narayanaswamy, P., Hugar, A. and Arunkumar, K.H. (2011).Genetic variability, correlation and path analysis in Okra (Abelmoschus esculentus (L.) Moench). Environment and Ecology. 29(2A): 778-782.

Sarkar, S., Hazra, P. and Chattopadhyay, A. (2004).Genetic variability, correlation and path analysis in Okra (Abelmoschus esculentus (L.) Moench). Horticultural J., 17(1): 59-66.

Saryam, D.K., Mittra, S.K., Mehta, A.K., Prajapati, S. and Kadwey, S. (2015).Correlation and path co-efficient analysis of quantitative traits in okra [Abelmoschus esculentus (L.) Moench]. Supplement on Genetics and Plant Breeding. 10(2): 735-739.

Senapati, N., Mishra, H.N., Beura, S.K., Dash, S.K., Prasad, G. and Patnaik, A. (2011). Genetic analysis in Okra hybrids.
Environment and Ecology. 29(3A): 12401244.

Sharma, A.K. and Prasad, K. (2015). Genetic divergence, correlation and path coefficient analysis in okra. Ind. J. Agric. Res., 49(1) : 77-82.

Sharma, R.K. and Prasad, K. (2010). Characterisation of promising okra genotypes on the basis of Principal Component Analysis. J. of Applied Horticulture. 12(1): 71-74.

Shivaramegowda, K.D., Krishnan, A., Jayaramu, Y. K., Kumar, V.,, Yashoda and Koh HeeJong (2016). Genotypic Variation among Okra (Abelmoschus esculentus (L.) Moench) Germplasms in South India. Plant Breed. Biotech. 4(2): 234-241.

Sreenivas, G., Arya, K. and Sheeba, R. (2015). Character association and path analysis for yield and yield components in okra [Abelmoschus esculentus (L.) Moench]. 4(1): 141-148

Verma, B.K., Naidu, A.K. and Bajpai, H.K. (2007). Correlation and path coefficient analysis in okra [Abelmoschus esculentus (L.) Moench] Abstract of International Conference on sustainable Agriculture for food, Bio-energy and livelihood security. Feb 14-16, 2007. Vol. II: 463.

Wright, S. (1921). System of mating. Genetics. 6:111-178

Yonas, M., Weyessa, G. and Adugna, D. (2014). Variablity and association of quantitative characters among okra (Abelmoschus esculentus (L.) Moench) collection in south Western Ethopiya. J. of Biological Sci., 14(5): 336-342.

\section{How to cite this article:}

Inderpreet Kaur Binepal, Swati Barche, Mandeep Kaur and Asati, K.P. 2019. Assessment of the Correlation and Path Analysis with Association of Growth and Yield Characteristics in Okra. Int.J.Curr.Microbiol.App.Sci. 8(05): 2331-2338.

doi: https://doi.org/10.20546/ijcmas.2019.805.275 